\title{
Firm size and technology centrality in industry-university interactions
}

\author{
Michael D. Santoro $^{a, *}$, Alok K. Chakrabarti ${ }^{b, c}$ \\ ${ }^{a}$ College of Business and Economics, Lehigh University, 621 Taylor Street, Bethlehem, PA 18015, USA \\ ${ }^{\mathrm{b}}$ Industrial Performance Center, Massachusetts Institute of Technology, Massachusetts, USA \\ c School of Management, New Jersey Institute of Technology, New Jersey, USA
}

Received 11 June 2000; received in revised form 17 October 2000; accepted 7 November 2001

\begin{abstract}
University research centers can be beneficial to industrial firms by providing firms with a number of relationship alternatives that facilitate the advancement of knowledge and new technologies. This multi-method field study indicates that larger more mechanistic firms especially those in resource intense industrial sectors use knowledge transfer and research support relationships to build competencies in non-core technological areas. In contrast, smaller more organic firms particularly those in high tech industrial sectors focus more on problem solving in core technological areas through technology transfer and cooperative research relationships. We also found that champions at the firm play a key role in these dynamics. Implications for industry and universities are discussed. (C) 2002 Elsevier Science B.V. All rights reserved.
\end{abstract}

Keywords: Industry-university collaboration; Relationship alternatives; Technology transfer; Alliances

\section{Introduction}

Intense global competition, rapid technological change, and shorter product life cycles have transformed the current competitive environment (Ali, 1994; Bettis and Hitt, 1995; Prahalad, 1998). Consequently, there are increased pressures on firms to continually advance knowledge and new technologies in order to ensure long-term prosperity and survival (Ali, 1994; Steele, 1989). While past practices favored internal initiatives, it is increasingly more difficult for firms to rely exclusively on in-house activities due to limited expertise and resources (Hamel and Prahalad,

\footnotetext{
* Corresponding author. Tel.: +1-610-758-6414; fax: 1-610-758-6941.

E-mail address: mds8@lehigh.edu (M.D. Santoro).
}

1994; Jarillo, 1988; Parkhe, 1993; Pisano, 1990; Shan et al., 1994).

Firms can acquire knowledge and technology from many external sources. These sources include competing firms, research organizations, government laboratories, industry research associations, and universities. Universities are unique in terms of their potential. Not only can a firm obtain knowledge and technology, but it can also recruit graduates and faculty to serve as employees and consultants. While much of the inter-organizational literature focuses on the collaboration between two or more industrial firms, we concentrate on industrial firm and university collaboration. Industry-university (I/U) alliances represent an evolving trend for advancing knowledge and new technologies (Cohen et al., 1998; NSB, 2000; Okubo and Sjoberg, 2000; SRI International, 1997). 
I/U relationships have a long history (Bower, 1993, 1992). Today, there continue to be compelling reasons for industrial firms and universities to work together. Benefits to a firm include access to highly trained students, facilities, and faculty as well as an enhanced image when collaborating with a prominent academic institution (Fombrun, 1996). Universities interact with industry for additional funds, particularly for research (NSB, 1996; NSF, 1982a). Universities also want to expose students and faculty to practical problems, create employment opportunities for their graduates, and gain access to applied technological areas (NSB, 1996, 2000). As a result of the complementary nature of I/U relationships, some of these collaborative activities have been instrumental in helping firms advance knowledge and propel new technologies in many areas, e.g. in biotechnology (Pisano, 1990), pharmaceuticals (van Rossum and Cabo, 1995) and manufacturing (Frye, 1993).

Geisler (1995) noted that many of the studies on $\mathrm{I} / \mathrm{U}$ collaboration do not have a strong theoretical foundation. While some cross-sectional studies have been reported in the literature (e.g. Cohen et al., 1998; NSB, 1996; SRI International, 1997), the overriding research design in these studies has been the small-sample case study (Geisler, 1995) with a focus on the university (Cohen et al., 1998; Mansfield, 1991). We underpin our work with several conceptual frameworks and concentrate on firm specific variables such as size, structure, and technological characteristics in order to examine the association between key firm specific variables and the various I/U relationship alternatives used by firms and universities.

\section{Conceptual framework and hypotheses}

We have focused on university research centers because these centers encourage diverse collaborative activities, they have identifiable formal structures, and they have an explicit mission to transfer knowledge with industrial firms (Betz, 1996; SRI International, 1997). From a policy perspective, university research centers are important areas of study as there have been conscious efforts to adopt this standard model to promote I/U collaboration (Santoro and Chakrabarti, 1999). The National Science Foundation in the US has taken a significant role in helping universities to organize research centers such as engineering research centers (ERCs) and I/U cooperative research centers (IUCRCs) in order to promote industry participation and stimulate technological advancement in certain key technology fields. Many university research centers have been established without any direct NSF support and these centers are also included in this study. While unique structural and contractual features distinguish university research centers, our focus is more holistic; on the key industry factors associated with various $\mathrm{I} / \mathrm{U}$ relationship alternatives across the variety of university research center models.

\subsection{Four important $I / U$ relationship alternatives}

Firms and university research centers work together in a variety of ways. Specifically, I/U relationships usually encompass four major inter-related components: research support, cooperative research, knowledge transfer, and technology transfer. We have developed a set of hypotheses linking several key industrial firm factors to each of these four $\mathrm{I} / \mathrm{U}$ relationships.

\subsubsection{Research support}

Research support is the least interactive of the four $\mathrm{I} / \mathrm{U}$ relationship components since research support embodies financial and equipment contributions made to universities by industry. Financial and equipment contributions can be unrestricted gifts or endowment trust funds that the university uses to upgrade laboratories, provide fellowships to graduate students, or provide seed money for promising new projects (Reams, 1986). In the past, industry often contributed large amounts of unrestricted funds and equipment for university research (Reams, 1986). Industry support for university research is now more targeted and often tied to specific research projects that pay dividends by providing industry with knowledge and new technologies for the long-term (Fortune, 1996).

\subsubsection{Cooperative research}

Cooperative research relationships are more interactive than research support and include contract research with individual investigators, consulting by faculty, and certain group arrangements specifically for addressing immediate industry problems (NSF, 1982a). Contract research with individual investigators 
and consulting are the most frequently used types of cooperative research and usually involve one faculty member working with a single firm on a targeted research project. Group arrangements involve more than just one faculty member and more than just one industrial firm. Here, the firm works with the university research center's faculty and staff through industry advisory boards and center-sponsored research seminars so the firm can pursue a specific initiative through a formal network with a coordinated research agenda (NSB, 1993).

\subsubsection{Knowledge transfer}

Knowledge transfer encompass a much broader array of highly interactive activities that include on-going formal and informal personal interactions, cooperative education, curriculum development, and personnel exchanges (Reams, 1986). On-going formal and informal personal interactions to transfer knowledge takes many forms. Examples of knowledge transfer mechanisms are $\mathrm{I} / \mathrm{U}$ research consortia, trade associations, and the co-authoring of research papers by university and industrial firm members (NSB, 2000; NSF, 1982b). Recruitment of recent university graduates and employing student interns continue to be chief ways knowledge is transferred between industry and academe (Phillips, 1991).

Knowledge transfer also happens through cooperative education programs which are designed to encourage information exchanges and on-the-job training experiences for undergraduate and graduate students (Phillips, 1991). Cooperative education programs help universities train students in state-of-the-art techniques ensuring that graduates meet industry's needs (Deutch, 1991).

\subsubsection{Technology transfer}

Technology transfer is the fourth I/U relationship component and like knowledge transfer also involves a number of highly interactive activities. Compared to knowledge transfer the focus here is on addressing immediate and more specific industry issues by leveraging university driven research with industry expertise and parlaying these complementary contributions into commercialized technologies needed by the marketplace (NSB, 2000; Teece, 1987). Often the university research center provides both basic and technical knowledge along with technology patent and/or licensing services while the industrial community provides knowledge in a specific applied area along with a clear problem statement related to market demand (Rea et al., 1997). Technology transfer occurs in many ways such as through technological consulting arrangements, the firm's use of center sponsored extension services, and jointly owned or operated ventures. Joint ventures usually represent large-scale commitments by both the firm and university to transfer technologies and are often based on successful prior relationships between the firm and the university research center (NSB, 1996).

To summarize, we have presented four distinct yet highly related ways in which industrial firms and university research centers work together to provide firms with an array of possibilities for pursuing different objectives related to advancing knowledge and new technologies. The next sections present a conceptual framework and hypotheses linking certain key industrial firm factors to these $\mathrm{I} / \mathrm{U}$ relationship alternatives. We developed our conceptual framework by integrating the literatures on inter-organizational cooperation (Browning et al., 1995; Hauschildt, 1999; Osborn and Hagedoorn, 1997; Smith et al., 1995), dynamic firm capabilities (Teece et al., 1997; Lado and Wilson, 1994; Barney, 1991), resource dependence (Pfeffer and Salancik, 1978; Wernerfelt, 1984), and power and influence (e.g. Pfeffer, 1981).

\subsection{Dynamic firm capabilities and technology centrality}

The process of knowledge and technology creation has been a central theme in much of the recent literature (Henderson and Cockburn, 1994; Deeds et al., 1998; Steele, 1989). The resource-based view of the firm is our starting point for investigating firms' internal resources, such as knowledge and capabilities, as sources of competitive advantage (Barney, 1991; Wernerfelt, 1984). Resource-based view considers only those resources that are rare, non-substitutable, and difficult to imitate as the foundation for sustainable competitive advantage (Barney, 1991). Subsequent research provides evidence that resources like knowledge and technology capabilities are important for the development of competitive advantage as they are often unique and difficult to imitate by competitors (Deeds et al., 1998; Henderson and Cockburn, 1994). 
Extending the resource-based view, the dynamic capabilities perspective emphasizes the ongoing development of capabilities underlying firm resources (Lado and Wilson, 1994; Mowery et al., 1996; Teece et al., 1997). It is not only resources that matter, but also how managers coordinate and integrate activities within the firm to best utilize and enhance these resources over time (Teece et al., 1997). Consistent with this evolutionary perspective of building and extending firm capabilities, the knowledge-based view of the firm (Grant and Baden-Fuller, 1995; Conner and Prahalad, 1996) emphasizes the firm's ability to integrate external sources of explicit and tacit knowledge. A central tenet of the dynamic capabilities view of the firm is that firms acquire new knowledge, skills, expertise, and capabilities through organizational learning (Deeds et al., 1998; Mowery et al., 1996) that can be described as "the act of bringing in or creating new knowledge" (Bierly and Chakrabarti, 1996, 369 pp.).

The need for ongoing improvement through organizational learning is necessary due to continual changes in technology (Steele, 1989), the speed of technological change (D'Aveni, 1994), and major changes in the overall competitive landscape for most firms (Bettis and Hitt, 1995; Prahalad, 1998). Organizational learning is not limited to the internal functioning of the firm, but often results by assimilating and integrating external knowledge (Cohen and Levinthal, 1990). Increasingly, inter-organizational relationships are important sources for acquiring external knowledge since they allow for the acquisition of supplementary and complementary capabilities held by their alliance partners while facilitating the flow of knowledge between partners (Kogut, 1988; Hamel, 1991; Teece, 1987).

Organizations are limited in the amount of skills and knowledge they can develop and maintain internally since firms have a finite group of people and a firm's ability to hire and fire is limited by such things as employment contracts, market conditions, and regulatory constraints (Hamel and Prahalad, 1994). Additionally, on-going organizational rightsizing can further bridle the influx of new people making the incumbent pool of people a core-rigidity (Leonard-Barton, 1995) further limiting the assimilation of new knowledge (Cohen and Levinthal, 1990). Since the rapid pace of technological change in many fields often renders skills and knowledge obsolete (Bettis and
Hitt, 1995), no organization is entirely self-sufficient (Pfeffer and Salancik, 1978). Therefore, exchange theories (e.g. Smith et al., 1995) suggest that collaboration between firms and universities can provide firms with skills, knowledge, and access to facilities needed to effectively evolve the firm's capabilities by exchanging complementary resources and growing competencies to generate value-added synergies (Teece, 1987). Beyond the building of dynamic capabilities, I/U collaboration can sometimes generate lower transaction costs (Osborn and Hagedoorn, 1997) with less risk (Frye, 1993) than alliances between industrial firms.

Firms have a variety of motivations for collaborating with university research centers. For example, large firms often pursue risky initiatives outside their current technological domain simply because they have the financial strength to do so (NSB, 1993, 2000, 1993; Rosner, 1968). Large firms work with universities on industry-wide, pre-competitive issues related to a broad range of leading-edge technologies, many of which are unrelated to the firm's core business (Rea et al., 1997). Relationships with universities are used by these firms to strengthen skills, knowledge, and gain access to university facilities in order to advance a broad range of knowledge bases useful in non-core technological areas. Since knowledge transfer and research support relationships are more suited for working on wide-ranging knowledge in a variety of technological areas, it follows that large industrial firms interested in non-core areas would concentrate their efforts in knowledge transfer and research support relationships. Since large firms use I/U relationships to bolster their work on technologies not central to their core business, these firms are less likely to engage in cooperative research and technology transfer activities since these relationships are better suited for pursuing core technological initiatives. Following this reasoning we formally propose.

Hypothesis 1. Large industrial firms have higher intensity knowledge transfer and research support relationships for strengthening skills, knowledge, and gaining access to university facilities for non-core technologies and lower intensity cooperative research and technology transfer relationships for strengthening skills, knowledge, and gaining access to university facilities for non-core technologies. 
In contrast to their larger counterparts, small firms are often bound by scarce financial resources and have a very limited pool of talents in-house (Acs and Audretsch, 1990). For many small firms leveraging core competencies in areas central to their business is a critical concern (Corsten, 1987; Foster, 1986). The I/U relationships can be beneficial here as well. Since small firms are often handicapped to successfully compete against their larger and more endowed competitors, I/U relationships are a way that smaller firms can help level the playing field. Smaller firms can use I/U relationships to strengthen skills, knowledge, and gain access to university facilities in order to advance core technologies that support the firm's central mission. Cooperative research and technology transfer relationships are especially appropriate for helping small firms advance core technologies since both these relationships involve targeted activities useful for addressing immediate issues in specific areas of opportunity. Since small firms primarily focus on advancing core-technologies they usually have less time and resources available for pursuing technologies outside their core domain. Consequently, small firms are less likely to engage in research support and knowledge transfer relationships since these relationships are better suited for pursuing non-core technologies. Thus,

Hypothesis 2. Small industrial firms have higher intensity technology transfer and cooperative research relationships for strengthening skills, knowledge and gaining access to university facilities for core technologies and lower intensity knowledge transfer and research support relationships for strengthening skills, knowledge, and gaining access to university facilities for core technologies.

\subsection{Power and influence - the role of champions}

Following Pfeffer's (1981) notion of power in organizations, certain organizational members are more influential than are others when it comes to advancing new ideas and initiatives. The ability to influence others often depends upon the organizational member's acquisition and use of power based on both structural and personal characteristics. Structural characteristics relate to the individual's physical position in the formal hierarchy and informal networks while personal characteristics include the individual's personal skills and physical traits (Pfeffer, 1981). Champions are individuals within an organization that exploit structural and personal characteristics to influence organizational dynamics in order to advance new ideas and initiatives (Chakrabarti, 1974).

Different authors describe the functions of champions differently although the basic theme of these descriptions remain the same, i.e. the ability to promote and influence an idea, project, or relationship (e.g. Schon, 1963; Chakrabarti, 1974; Chakrabarti and Hauschildt, 1989; Howell and Higgins, 1990). Since champions are usually sanctioned by an organization's top management, the champion's formal position and position power is legitimized (Pfeffer, 1981). Effective champions also know how to properly posture themselves into the organization's informal network (Schon, 1963). With respect to personal characteristics, research indicates that effective champions are technologically knowledgeable, spontaneous to dynamic market conditions, aggressive, have a strong sense of drive, are politically astute, and are skillful boundary managers (Chakrabarti, 1974; Smith et al., 1984). Effective champions are also persistent, persuasive, and innovative (Howell and Higgins, 1990). Thus, a champion's physical position in an organization combined with their unique personal characteristics and skills underpin their power-base and their ability to influence others in many crucial organizational activities (Pfeffer, 1981).

Successful I/U relationships require that universities must be willing to get involved in research that industry deems valuable. In the same way, industry must be made aware of and be willing to employ the types of research that universities are conducting. In bridging this gap, key intermediaries and liaisons in each organization must ensure that there is frequent, on-going, and personal involvement between university researchers and industry managers. Champions serve this important role (Evans et al., 1993; Gerwin et al., 1992; NSF, 1982a; SRI International, 1997). As the key contact and liaison, effective I/U champions must be sensitive to each organization's needs, mission, and objectives (van Dierdonck et al., 1990). Effective champions often serve as scouts who seek external information affecting the relationship, ambassadors who maintain good relations between 
the two organizations, coordinators who monitor and facilitate on-going collaborative activities, and guards who protect against any internal and external threats to the alliance (Ancona and Caldwell, 1990).

Previous work suggests that successful I/U relationships require champions at both the firm and the university (e.g. Gerwin et al., 1992; van Dierdonck et al., 1990). We contend, however, that some champions are more important than are others. As the firm's chief promoter and influencer for its I/U relationship, industrial firm champions use their power, both position and personal, to influence others about the value of collaborating with a university partner. Moreover, the firm's champion must often overcome opposition and resistance to an I/U alliance (Hauschildt, 1999). Additionally, since the industrial firm ultimately determines its level of involvement in I/U relationships (Santoro and Chakrabarti, 1999), the firm's champion is, therefore, the key player in this linkage. Consequently, we contend that an industrial firm champion is more influential to I/U relationships than a university research center champion. More formally,

Hypothesis 3. The presence of an $\mathrm{I} / \mathrm{U}$ champion at the industrial firm is associated with higher intensity relationships across all four I/U relationship alternatives compared to the presence of an I/U champion at the university research center.

\subsection{Organizational structure}

Much research in organization theory has clearly demonstrated that organization structure is closely linked to firm size and plays a role in a firm's ability to adapt to the environment, create and assimilate knowledge, and be innovative (Burns and Stalker, 1961; Lawrence and Lorsch, 1967). Organizational structure is also a consequential factor that directly impacts dynamic firm capabilities (Teece et al., 1997). As such, an organization's structure affects both knowledge and technology transfer since knowledge and/or technology transfer involves identifying the appropriate sources, interacting with those sources, acquiring the knowledge and/or technology, and integrating them into existing organizational systems and procedures (Zmud, 1982).
Burns and Stalker (1961) identified three dimensions to characterize an organization's structure as either mechanistic or organic: (1) the number of hierarchical levels, (2) the extent to which knowledge and control are concentrated at the top of the organization (centralization), and (3) the degree of adherence to rules and policies (formalization). Daft (1978) argued that new technologies or technical innovations follow a bottom up process originating in the technical core percolating up into higher levels of the organization. In contrast, administrative innovations originate in the administrative core, i.e. at higher levels of the organization, and flow down to lower levels of the organization through a top-down process.

We argue that certain I/U relationship activities like technology transfer and cooperative research relationships incorporate and demand specific technical knowledge from the technical cores of both organizations, therefore, resembling Daft's (1978) notion of technical innovations. For example, technology transfer happens through a dense network of individual ties between university scientists and engineers and industrial firm R and D personnel (Oliver and Liebeskind, 1998). The ability to transfer technology by working on targeted initiatives depends on the firm's ability to accurately understand, interpret, evaluate, and absorb specific knowledge and technologies. This is better accomplished when the engineers and technical personnel who fully understand the language and concepts used by university scientists and researchers are able to interact freely (Gittelman, 2000). Free and flexible interactions often require that the firm has a more decentralized, informal, and flatter, i.e. a more organic, structure. Thus, organic structures better facilitate technology transfer and cooperative research activities.

On the other hand, we believe that knowledge transfer relationships and research support relationships are more closely aligned with the properties of Daft's (1978) administrative innovations. That is, knowledge transfer and research support entail broader, more visionary and strategic issues of how to manage and how to develop and use the knowledge and new technologies that serve marketplace needs. Moreover, both knowledge transfer and research support relationships tend to revolve around more amorphous and unspecific constructs having longer-term implications (NSF, 1982b). Consequently, knowledge transfer and 
research support relationships require greater top management involvement as top managers provide initial approval and convey their directives to organizational personnel in a top-down manner. Following these linkages between a firm's structure and certain $\mathrm{I} / \mathrm{U}$ relationships, we propose the following:

Hypothesis 4. Industrial firms with more organic structures have higher intensity technology transfer and cooperative research I/U relationships while firms with more mechanistic structures have higher intensity knowledge transfer and research support I/U relationships.

\section{Method}

\subsection{Overall research approach}

A multi-method field study was used to investigate this complex phenomenon. First, two different sources of exploratory data were obtained including an initial analysis of 12 recent NSF program evaluations and survey protocols. Next, 15 semi-structured interviews were conducted with industrial firm representatives and university center directors. The combined exploratory data helped to clarify and substantiate our conceptual framework while the semi-structured interviews also served to refine and provide face validity to our survey questionnaire (Cook and Campbell, 1976).

Upon completion of the exploratory data, a variety of university research centers in prominent public and private US universities were contacted. Twenty-nine university research centers were originally contacted, 21 agreed to participate in this study (approval rate of $72 \%$ ). Those opting not to participate did so largely due to time and resource constraints. The 21 participating university research centers provided complete lists of their corporate partners. A survey questionnaire was then mailed to each industrial firm representative identified and this data were used for hypotheses testing.

To complete the data collection, in-depth, structured interviews were conducted in order to validate the survey questionnaire data and to obtain additional details. Interviews were conducted with 31 firms in the semiconductors (10 firms), metals and fabricated metals (12 firms), manufacturing (5 firms), and biotechnology (4 firms) industrial sectors.

\subsection{Sample}

The 21 participating university research centers consisted of eight NSF supported engineering research centers, eight NSF supported I/U cooperative research centers, and five research centers outside these models. The 21 centers represented a diverse, cross-section of disciplines, e.g. optics, large structural systems, off shore drilling, with a wide variation of member companies. This wide cross-section of firms and research centers provided us with the possibility for greater generalizability beyond the idiosyncratic nature of one particular center or limited industry environments. On average, each research center works with twenty industrial firms. In total, the 21 centers collaborate with 421 industrial firms. Survey questionnaires were sent to all 421 firms. A total of 207 questionnaires were returned, but five were missing significant data. Thus, 202 responses were useable for a response rate of $48 \%$. An analysis was conducted to determine if any response bias existed. No significant differences were found between those responding compared to those not responding based on firm size, industrial sector, partnering research center, or length of relationship.

Five of the participating firms had more than one person involved in their I/U relationships. In these situations, survey questionnaires were sent to each participant within the firm with the multiple responses aggregated into one score for the firm. That is, the average of the two responses in three firms or in two firms the three responses, were used to reflect the firm's collective insight on their relationship with the university research center (Rosenthal and Rosnow, 1991). The data aggregation was done since each participant was knowledgeable about the I/U relationship and each had a significant stake in the relationship. Moreover, the participants were homogeneous since formal I/U relationship objectives existed in each of the firms. Homogeneity was confirmed by high inter-rater reliability (Spearman-Brown formula = 0.74 mean individual and 0.85 mean aggregate reliability for two participants and 0.71 mean individual and 0.89 mean aggregate reliability for three participants). As a result of data aggregation, our sample size for analyses was 189 . Finally, using Lawrence's (1984) industry categorization scheme, 120 of the firms were classified as high tech, 33 firms capital 
intense, 27 firms resource intense, and 9 firms labor intense.

\subsection{Measures}

The measures used in this study were adapted from the existing literature. Based on our exploratory interviews, modifications were made to some of the items to properly tap into this study's specific constructs. All measures utilized seven-point Likert-type scales, except for firm size and industrial sector, and all were multi-item scales, except for firm size, industrial sector, and I/U champions. The $\alpha$-coefficients and references to the appropriate literature are included with each description below.

\subsubsection{Dependent variable}

3.3.1.1. Firm's level of intensity in I/U relationships. A 19 item scale $(\alpha=0.91)$ was used to measure the four factors representing our dependent variable. Seven-point Likert scales measured the intensity of the following 19 activities specifically related to advancing knowledge and new technologies: (1) percentage of research funds allocated to the center, (2) level of contract research, (3) level of grant dollars, (4) level of participation in research center sponsored consortia, (5) level of participation in jointly-owned or operated facilities, (6) level of participation in co-authoring research papers with university center researchers, (7) number of recent university graduates hired by the firm, (8) percentage of research consulting expenditures paid to center as a percentage of firm's total research budget, (9) level of joint decision-making in technological consulting arrangements (10) number of personnel exchanges, (11) level of participation in center sponsored research seminars, (12) level of participation in center advisory boards for directing research agendas, (13) number of student interns hired by the firm, (14) firm's involvement in curriculum development, (15) firm's involvement in the use of cooperative education programs, (16) level of participation in center sponsored trade associations, (17) level of participation in center sponsored extension services for creating new technologies, (18) time spent interacting with center personnel specifically for advancing new technologies, and (19) level of joint decision-making with center to advance new technologies.
A factor analysis was performed to empirically validate the four separate I/U relationship components of research support, cooperative research, knowledge transfer, and technology transfer. Using principal components extraction four factors did indeed surface. Table 1 indicates that the eigenvalues for each of the four factors ranged from 8.1 to 1.7 with the combination of factors explaining nearly $79 \%$ of the variance. Table 1 also shows the VARIMAX rotation factor loadings where 0.5 was used as the loading threshold (Hair et al., 1995).

Following the factor analysis results, knowledge transfer represents the firm's level of involvement in a variety of highly interactive activities directly related to transferring both explicit and tacit knowledge between the firm and the university research center $(\alpha=0.91)$. Technology transfer is the firm's level of involvement in a variety of interactive activities directly related to the advancement of new technologies $(\alpha=0.92)$. Cooperative research is the firm's level of involvement in working with certain research center personnel and groups on specific applied research initiatives $(\alpha=0.88)$ while research support represents the firm's commitment to advancing new technologies expressed through grants and overall research funding to the center $(\alpha=0.92)$.

\subsubsection{Independent variables}

\subsubsection{Strengthen skills, knowledge, and gain access} to university facilities for essential, core technologies. The dynamic capabilities and resource dependency in the area of core technologies embodied two dimensions. The first dimension contained two items related to the firm's needs: (1a) the importance of strengthening critical skills and knowledge for advancing essential, core technologies and (1b) the importance of gaining access to physical tools, equipment, and systems necessary for advancing essential, core technologies. The second dimension contained two items related to the firm's perception of the university research center's ability to satisfy the firm's needs: (2a) the importance of the university center having needed skills and knowledge for advancing essential, core technologies and ( $2 b)$ the importance of the university center having needed physical tools, equipment, and systems to facilitate the firm's advancing of essential, 
Table 1

VARIMAX rotation factor loadings

\begin{tabular}{|c|c|c|c|c|}
\hline Items & $\begin{array}{l}\text { Factor 1, } \\
\text { knowledge } \\
\text { transfer }\end{array}$ & $\begin{array}{l}\text { Factor } 2 \text {, } \\
\text { technology } \\
\text { transfer }\end{array}$ & $\begin{array}{l}\text { Factor } 3 \text {, } \\
\text { cooperative } \\
\text { research }\end{array}$ & $\begin{array}{l}\text { Factor } 4, \\
\text { research } \\
\text { support }\end{array}$ \\
\hline Firm's involvement in curriculum development & 0.81 & & & \\
\hline Student interns hired by the firm as direct result of $\mathrm{I} / \mathrm{U}$ relationship & 0.78 & & & \\
\hline Firm's involvement in cooperative education programs & 0.77 & & & \\
\hline Recent university graduates hired by the firm & 0.75 & & & \\
\hline Level of participation in research center sponsored consortia & 0.71 & & & \\
\hline Level of participation in research center sponsored trade associations & 0.58 & & & \\
\hline Level of participation in co-authoring research papers & 0.52 & & & \\
\hline Number of personnel exchanges with research center & 0.52 & & & \\
\hline $\begin{array}{l}\text { Time spent interacting with center personnel specifically for advancing } \\
\text { new technologies }\end{array}$ & & 0.83 & & \\
\hline $\begin{array}{l}\text { Level of joint decision-making in technological consulting arrange- } \\
\text { ments }\end{array}$ & & 0.79 & & \\
\hline $\begin{array}{l}\text { Level of joint decision-making with center personnel specifically for } \\
\text { advancing new technologies }\end{array}$ & & 0.74 & & \\
\hline $\begin{array}{l}\text { Level of participation in jointly owned or operated facilities specifically } \\
\text { for advancing new technologies }\end{array}$ & & 0.69 & & \\
\hline $\begin{array}{l}\text { Level of participation in center sponsored extension services for new } \\
\text { technologies }\end{array}$ & & 0.58 & & \\
\hline Level of contract research & & & 0.84 & \\
\hline $\begin{array}{l}\text { Percentage of research consulting expenditures paid to center as } \% \text { of } \\
\text { firm's total research budget }\end{array}$ & & & 0.78 & \\
\hline $\begin{array}{l}\text { Level of participation in research center advisory boards for directing } \\
\text { research agendas }\end{array}$ & & & 0.67 & \\
\hline Level of participation in research center sponsored research seminars & & & 0.53 & \\
\hline Level of grant dollars specifically for advancing new technologies & & & & 0.80 \\
\hline $\begin{array}{l}\text { Percentage of research funds allocated to center specifically for ad- } \\
\text { vancing new technologies }\end{array}$ & & & & 0.77 \\
\hline Eigenvalues & 8.1 & 4.5 & 2.3 & 1.7 \\
\hline Explained variance & 43.5 & 14.7 & 11.4 & 8.8 \\
\hline Cumulative explained variance & 43.5 & 58.2 & 69.6 & 78.4 \\
\hline
\end{tabular}

core technologies (NSB, 1996). In total, a four-item scale $(\alpha=0.93)$ was used.

\subsubsection{Strengthen skills, knowledge, and gain access} to university facilities for ancillary, non-core technologies. The dynamic capabilities and resource dependency in the area of non-core technologies also embodied two-dimensions. The first dimension contained two items related to the firm's needs: (1a) the importance of strengthening critical skills and knowledge for advancing ancillary, non-core technologies and (1b) the importance of gaining access to physical tools, equipment, and systems necessary for advancing an- cillary, non-core technologies. The second dimension contained two items related to the firm's perception of the university research center's ability to satisfy the firm's needs: (2a) the importance of the university center having needed skills and knowledge for advancing ancillary, non-core technologies and (2b) the importance of the university center having needed physical tools, equipment, and systems to facilitate the firm's advancing of ancillary, non-core technologies (NSB, 1996). In total, a four-item scale $(\alpha=0.91)$ was used.

\subsubsection{Presence of an industrial firm I/U champion.} A one-item scale was used to capture the presence 
and influence of a dedicated individual at the firm who served as the $\mathrm{I} / \mathrm{U}$ champion defined by maintaining on-going relations, monitoring the relationship's on-going activities, and guarding against any internal or external threats to the on-going relationship (Ancona and Caldwell, 1990).

\subsubsection{Presence of a university research center $I / U$} champion. A one-item scale was used to capture the presence and influence of a dedicated individual at the university research center who served as the I/U champion defined by maintaining on-going relations, monitoring the relationship's on-going activities, and guarding against any internal or external threats to the on-going relationship (Ancona and Caldwell, 1990).

\subsubsection{Firm size. This variable was measured by} the number of employees within the firm (Corsten, 1987). Following the small business administration's classification, firm size was coded as a categorical variable where a " 1 " represented small firms, those having $<500$ employees while a " 2 " represented large firms, those having 500 employees and more. A total of 125 firms or $66 \%$ were large while 64 of the firms or $34 \%$ were small.

\subsubsection{Firm structure. A three-item scale $(\alpha=$} 0.75) was used. Following Burns and Stalker (1961), the firm's structure was represented by the number of hierarchical levels within the firm, the extent to which members follow directives (extent of centralization), and the extent to which the firm has rigid rules and policies (extent of formalization). Firms scoring high on these three-dimensions were classified as mechanistic those scoring low were classified as organic.

Beyond the variables of interest presented above, we also included the firm's industrial sector as a control variable. We chose to control for the firm's industrial sector since I/U activities are highly sector specific (NSB, 1996, 2000).

\subsubsection{Industrial sector. An industry code from 1} to 21 was initially assigned to each firm using the firm's two-digit SIC code. The firm's two-digit SIC codes were obtained through a combination of Dun and Bradstreet's Business Report and InfoUSA. For parsimony, we used Lawrence's (1984) industry typology to consolidate the 21 industries representing the firms in this study into the four industrial categories of high tech, capital intense, labor intense, and resource intense. High tech firms were those in industrial sectors such as biotechnology, microcomputers, semiconductors, and electronics. Capital intense firms included the manufacturing sectors while labor intense firms represented firms in service industries. Resource intense firms included firms in sectors such as lumber and paper products, petroleum, and mining.

\section{Results}

Table 2 provides descriptive statistics and the correlation matrix. Table 2 indicates a number of strong correlations among several of the independent variables and the dependent variables. Since a number of the independent variables were also highly correlated to one another, a multi-collinearity analysis was conducted to examine this more closely. The results of this analysis indicated that multi-collinearity was not a significant issue since none of the variance inflation factors for any of the variables exceeded 1.4 (Hair et al., 1995). Upon completing this regression diagnostic, multiple regression analysis was then used for hypotheses testing.

Eight regression models, provided in Table 3, were developed to test our four hypotheses. In Models 1a, $2 \mathrm{a}, 3 \mathrm{a}$, and $4 \mathrm{a}$ we regressed the main effect variables and the control variable on each of the four dependent variables, i.e. knowledge transfer, technology transfer, cooperative research, and research support. The following equations explicate the specific variables included in each of these four regression models:

(1a) Knowledge transfer $=a_{0}+a_{1}$ skills, knowledge and facilities for non-core technologies + $a_{2}$ skills, knowledge and facilities for core technologies $+a_{3}$ firm size $+a_{4}$ champion at the firm $+a_{5}$ champion at the research center $+a_{6}$ firm structure $+a_{7}$ industrial sector $+e_{1}$

(2a) Technology transfer $=b_{0}+b_{1}$ skills, knowledge and facilities for non-core technologies + $b_{2}$ skills, knowledge and facilities for core technologies $+b_{3}$ firm size $+b_{4}$ champion at the firm $+b_{5}$ champion at the research center $+b_{6}$ firm structure $+b_{7}$ industrial sector $+e_{2}$ 
Table 2

Means, S.D. and bi-variate correlations ${ }^{\mathrm{a}}$

\begin{tabular}{|c|c|c|c|c|c|c|c|c|c|c|c|c|}
\hline Variable & Mean & S.D. & 1 & 2 & 3 & 4 & 5 & 6 & 7 & 8 & 9 & 10 \\
\hline Knowledge transfer & 2.9 & 1.5 & & & & & & & & & & \\
\hline Technology transfer & 3.3 & 1.6 & $0.38^{* * *}$ & & & & & & & & & \\
\hline Cooperative research & 2.4 & 0.9 & $0.33^{* * *}$ & $0.30^{* * *}$ & & & & & & & & \\
\hline Research support & 2.3 & 0.9 & $0.31^{* * *}$ & $0.29^{* * *}$ & $0.32^{* * *}$ & & & & & & & \\
\hline $\begin{array}{l}\text { Skills, etc. for non-core } \\
\text { technologies }\end{array}$ & 5.4 & 1.3 & $0.41^{* * *}$ & $0.15^{*}$ & $0.28^{* * *}$ & $0.33^{* * *}$ & & & & & & \\
\hline $\begin{array}{l}\text { Skills, etc. for core } \\
\text { technologies }\end{array}$ & 4.3 & 1.2 & $0.18^{* *}$ & $0.43^{* * *}$ & $0.35^{* * *}$ & $0.17^{*}$ & $0.56^{* * *}$ & & & & & \\
\hline $\begin{array}{l}\mathrm{I} / \mathrm{U} \text { champion at } \\
\text { industrial firm }\end{array}$ & 5.9 & 1.1 & $0.40^{* * *}$ & $0.24^{* * *}$ & $0.21^{* * *}$ & $0.19^{* *}$ & $0.43^{* * *}$ & $0.24^{* * *}$ & & & & \\
\hline $\begin{array}{l}\mathrm{I} / \mathrm{U} \text { champion at } \\
\text { research center }\end{array}$ & 5.7 & 1.2 & $0.20^{* *}$ & $0.16^{*}$ & $0.13^{*}$ & 0.09 & 0.10 & 0.08 & $0.17^{*}$ & & & \\
\hline Firm size & 0.66 & 0.48 & $-0.19^{* *}$ & $0.20^{* *}$ & $-0.29^{* * *}$ & $0.52^{* * *}$ & $0.42^{* * *}$ & $-0.39^{* * *}$ & $0.21^{* * *}$ & $0.27^{* * *}$ & & \\
\hline Firm structure & 4.4 & 1.1 & $0.22^{* * *}$ & -0.09 & $-0.19^{* *}$ & $0.18^{* *}$ & $0.22^{* * *}$ & $-0.13^{*}$ & $0.16^{*}$ & 0.09 & $0.29^{* * *}$ & \\
\hline Industrial sector & 2.4 & 0.8 & $-0.37^{* * *}$ & $0.32^{* * *}$ & 0.07 & $-0.20^{* *}$ & $-0.29^{* * *}$ & $0.32^{* * *}$ & $-0.20^{* *}$ & $0.14^{*}$ & $-0.34^{* * *}$ & $0.23^{* * *}$ \\
\hline
\end{tabular}

$$
\begin{aligned}
& { }^{\mathrm{a}} N=189 . \\
& { }^{*} P<0.05 . \\
& { }^{* *} P<0.01 . \\
& { }^{* * *} P<0.001 .
\end{aligned}
$$

\begin{tabular}{|c|c|c|c|c|c|c|c|c|}
\hline \multirow[t]{2}{*}{ Variable } & \multicolumn{2}{|c|}{ Knowledge transfer } & \multicolumn{2}{|c|}{ Technology transfer } & \multicolumn{2}{|c|}{ Cooperative research } & \multicolumn{2}{|c|}{ Research support } \\
\hline & Model 1a & Model 1b & Model 2a & Model 2b & Model 3a & Model 3b & Model 4a & Model 4b \\
\hline $\begin{array}{l}\text { Skills, knowledge and access to } \\
\text { facilities for advancing } \\
\text { non-core technologies }\end{array}$ & $0.20^{* * *}$ & $0.12^{*}$ & 0.08 & 0.07 & $0.13^{*}$ & $0.12^{*}$ & $0.20^{* * *}$ & $0.17^{* *}$ \\
\hline $\begin{array}{l}\text { Skills, knowledge and access to } \\
\text { facilities for advancing } \\
\text { core technologies }\end{array}$ & $0.11^{*}$ & 0.09 & $0.24^{* * *}$ & $0.19^{* *}$ & $0.22^{* * *}$ & $0.18^{* *}$ & $0.16^{* *}$ & $0.14^{*}$ \\
\hline Firm size & 0.05 & 0.04 & 0.08 & 0.02 & $-0.21^{* * *}$ & $-0.19^{* *}$ & $0.23^{* * *}$ & $0.16^{* *}$ \\
\hline $\begin{array}{l}\text { Skills, knowledge and access } \\
\text { to facilities for advancing } \\
\text { non-core technologies } \times \text { firm size }\end{array}$ & & $0.26^{* * *}$ & & $0.13^{*}$ & & $0.12^{*}$ & & $0.24^{* * *}$ \\
\hline $\begin{array}{l}\text { Skills, knowledge and access to facilities } \\
\text { for advancing core technologies } \\
\times \text { firm size }\end{array}$ & & $0.11^{*}$ & & $-0.26^{* * *}$ & & $-0.22^{* * *}$ & & $0.13^{*}$ \\
\hline $\mathrm{I} / \mathrm{U}$ champion at industrial firm & $0.22^{* * *}$ & $0.21^{* * *}$ & $0.18^{* *}$ & $0.18^{* *}$ & $0.21^{* * *}$ & $0.19^{* *}$ & $0.23^{* * *}$ & $0.22^{* * *}$ \\
\hline $\begin{array}{l}\mathrm{I} / \mathrm{U} \text { champion at university research } \\
\text { center }\end{array}$ & $0.12^{*}$ & $0.12^{*}$ & 0.07 & 0.07 & 0.10 & 0.08 & $0.11^{*}$ & 0.10 \\
\hline Firm structure & $0.17^{* *}$ & $0.16^{* *}$ & -0.04 & -0.04 & $-0.14^{*}$ & $-0.14^{*}$ & 0.07 & 0.06 \\
\hline Industrial sector (control variable) & $-0.18^{* *}$ & $-0.18^{* *}$ & $0.21^{* *}$ & $0.20^{* *}$ & 0.03 & 0.03 & $-0.12^{*}$ & $-0.12^{*}$ \\
\hline Overall $F$ & $18.6^{* * *}$ & $23.7^{* * *}$ & $14.4^{* * *}$ & $16.4^{* * *}$ & $17.7^{* * *}$ & $20.3^{* * *}$ & $16.2^{* * *}$ & $21.2^{* * *}$ \\
\hline Adjusted $R^{2}$ & 0.31 & 0.41 & 0.22 & 0.29 & 0.30 & 0.37 & 0.28 & 0.39 \\
\hline
\end{tabular}

Table 3

Regression analyses: firm's intensity of each I/U relationship alternative as the dependent variable ${ }^{\mathrm{a}}$

${ }^{\text {a }}$ Regression coefficients are standardized, $N=189$.

${ }^{*} P<0.05$.

** $P<0.01$

*** $P<0.001$. 
(3a) Cooperative research $=c_{0}+c_{1}$ skills, knowledge and facilities for non-core technologies + $c_{2}$ skills, knowledge and facilities for core technologies $+c_{3}$ firm size $+c_{4}$ champion at the firm $+c_{5}$ champion at the research center $+c_{6}$ firm structure $+c_{7}$ industrial sector $+e_{3}$

(4a) Research support $=d_{0}+d_{1}$ skills, knowledge and facilities for non-core technologies + $d_{2}$ skills, knowledge and facilities for core technologies $+d_{3}$ firm size $+d_{4}$ champion at the firm $+d_{5}$ champion at the research center $+d_{6}$ firm structure $+d_{7}$ industrial sector $+e_{4}$

In Models $1 b, 2 b, 3 b$, and $4 b$ we regressed the main effect variables, the control variable, and the interaction terms on each of the four dependent variables. The following equations explicate the specific variables included in each of these four regression models:

(1b) Knowledge transfer $=a_{0}+a_{1}$ skills, knowledge and facilities for non-core technologies + $a_{2}$ skills, knowledge and facilities for core technologies $+a_{3}$ firm size $+a_{4}$ skills, knowledge and facilities for non-core technologies $\times$ firm size $+a_{5}$ skills, knowledge and facilities for core technologies $\times$ firm size $+a_{6}$ champion at the firm $+a_{7}$ champion at the research center $+a_{8}$ firm structure $+a_{9}$ industrial sector $+e_{1}$

(2b) Technology transfer $=b_{0}+b_{1}$ skills, knowledge and facilities for non-core technologies + $b_{2}$ skills, knowledge and facilities for core technologies $+b_{3}$ firm size $+b_{4}$ skills, knowledge and facilities for non-core technologies $\times$ firm size $+b_{5}$ skills, knowledge and facilities for core technologies $\times$ firm size $+b_{6}$ champion at the firm $+b_{7}$ champion at the research center $+b_{8}$ firm structure $+b_{9}$ industrial sector $+e_{2}$

(3b) Cooperative research $=c_{0}+c_{1}$ skills, knowledge and facilities for non-core technologies + $c_{2}$ skills, knowledge and facilities for core technologies $+c_{3}$ firm size $+c_{4}$ skills, knowledge and facilities for non-core technologies $\times$ firm size $+c_{5}$ skills, knowledge and facilities for core technologies $\times$ firm size $+c_{6}$ champion at the firm $+c_{7}$ champion at the research center $+c_{8}$ firm structure $+c_{9}$ industrial sector $+e_{3}$

(4b) Research support $=d_{0}+d_{1}$ skills, knowledge and facilities for non-core technologies + $d_{2}$ skills, knowledge and facilities for core technologies $+d_{3}$ firm size $+d_{4}$ skills, knowledge and facilities for non-core technologies $\times$ firm size $+d_{5}$ skills, knowledge and facilities for core technologies $\times$ firm size $+d_{6}$ champion at the firm $+d_{7}$ champion at the research center $+d_{8}$ firm structure $+d_{9}$ industrial sector $+e_{4}$

Linear-by-linear interaction terms were created by multiplying the proposed moderator with the target independent variables (Hair et al., 1995; Stone and Hollenbeck, 1988). After entering the proposed main effects and control variables into the regression equation (Models 1a, 2a, 3a, and 4a), the multiplicative terms were then added (Models 1b, 2b, 3b, and 4b). A comparison of the standardized regression coefficients and the change in Adjusted $R^{2}$ in each of the models were then examined for significance (Hair et al., 1995; Stone and Hollenbeck, 1988).

Using the moderated multiple regression analyses provided in Table 3 we find support for Hypothesis 1. Our results indicate that large firms have higher intensity knowledge transfer and research support relationships and lower intensity cooperative research and technology transfer relationships for strengthening skills, knowledge, and gaining access to university facilities for ancillary, non-core technologies. A comparison of the moderated regression models in Table 3 also provides support for Hypothesis 2. Our results indicate that small firms have higher intensity cooperative research and technology transfer relationships and lower intensity knowledge transfer and research support relationships for strengthening skills, knowledge, and gaining access to university facilities for essential, core technologies.

A comparison of the standardized regression coefficients across regression models $1 \mathrm{a}, 2 \mathrm{a}, 3 \mathrm{a}$, and $4 \mathrm{a}$ indicate that an I/U champion at the firm is associated with higher intensity relationships across all four relationship alternatives compared to an $\mathrm{I} / \mathrm{U}$ champion at the university research center. This finding supports Hypothesis 3.

With respect to firm structure, a comparison of the standardized coefficients across regression Models 1a, 2a, 3a, and 4a provides only partial support for Hypothesis 4. Our results show that firms with more mechanistic structures had higher intensity knowledge transfer and research support relationships. While firms with more organic structures had higher cooper- 
ative research relationships, firms with more organic structures did not have higher intensity technology transfer relationships.

Finally, in controlling for the firm's industrial sector we found evidence supporting the notion that industrial sector is consequential within the I/U collaborative dynamic. To examine the initial results from the multiple regression analyses more closely, we performed a comprehensive ANOVA using contrasts to compare our four industrial sector categories of high tech, labor intense, capital intense, and resource intense. The ANOVA contrasts revealed that firms in high tech industries were more associated with technology transfer $(P<0.001)$ and cooperative research relationships $(P<0.05)$ while firms in resource intense industries were more associated with knowledge transfer $(P<0.01)$ and research support relationships $(P<0.05)$.

\section{Discussion and implications}

The results of this study show that industrial firms use a variety of relationships with university research centers to accomplish different things. More specifically, we found that large firms have higher intensity knowledge transfer and research support relationships in order to strengthen skills and knowledge and gain access to university facilities for advancing non-core technologies. In contrast, small firms have higher intensity technology transfer and cooperative research relationships in order to strengthen skills and knowledge and gain access to university facilities for advancing core technologies. Fig. 1 expands upon this dynamic. In integrating other aspects of our findings to this model, we also provide policy implications in the discussion below.

Since large firms are usually endowed with more resources, particularly financial (Rosner, 1968) they have the ability to diversify into non-core areas. In pursuing opportunities in non-core areas large firms use knowledge transfer and research support relationships to build new competencies and create enabling technologies in ancillary areas that are not central to the firm's core business (Quadrant I). Our finding is consistent with the findings in the corporate strategy literature that firms will seldom outsource technology in its core competence area (e.g. Prahalad and Hamel, 1990). On the other hand, it makes great sense to outsource technology development that is outside the realm of the firm's core competence. Conversely, small firms have a very different focus in their I/U relationships because of the many additional constraints that they have. Unlike their larger counterparts, small firms are not primarily interested in using I/U relationships for long-term competency building in non-core areas. Small firms are usually most concerned with survival (Steele, 1989) and therefore participate more in $\mathrm{I} / \mathrm{U}$ relationships that provide immediate solutions to critical issues affecting central business areas and core technologies (Quadrant IV).

Our results seem to show that industrial firms do not typically use university relationships to help strengthen and build core competencies (Quadrant II). We believe that the cultural and philosophical differences that still largely exist between industry and academe may be a key reason (IRI, 1995; Reams, 1986). For example, universities have an orientation

\begin{tabular}{|c|c|c|}
\hline & $\begin{array}{c}\text { Focus on Non-Core } \\
\text { Technologies }\end{array}$ & $\begin{array}{c}\text { Focus on Core } \\
\text { Technologies }\end{array}$ \\
\hline $\begin{array}{c}\text { Use of Knowledge } \\
\text { Transfer and } \\
\text { Research Support } \\
\text { Relationships }\end{array}$ & $\begin{array}{c}\text { I. Competence Building in } \\
\text { Ancillary Areas }\end{array}$ & $\begin{array}{c}\text { II. Competence Building in } \\
\text { Essential Areas Central to the } \\
\text { Business }\end{array}$ \\
\hline $\begin{array}{c}\text { Use of Technology } \\
\text { Transfer and } \\
\text { Cooperative } \\
\text { Research } \\
\text { Relationships }\end{array}$ & $\begin{array}{l}\text { III. Problem Solving in } \\
\text { Ancillary Areas }\end{array}$ & $\begin{array}{c}\text { IV. Problem Solving in } \\
\text { Essential Areas Central to the } \\
\text { Business }\end{array}$ \\
\hline
\end{tabular}

Fig. 1. Competence building and problem solving strategies employed by firms in I/U relationships. 
towards time and goals that are quite different from industrial firms (Lawrence and Lorsch, 1967). Moreover, firms may be fearful to depend on universities in areas that are at the heart of defining their organization or that are so acute for creating competitive advantage (Hamel and Prahalad, 1994). Our findings also appear to indicate that industrial firms do not use $\mathrm{I} / \mathrm{U}$ relationships for problem solving in ancillary or non-central areas (Quadrant III). While currently an underemployed area, this could be very fruitful for many firms especially since university research centers can provide firms with complementary skills, knowledge, and resources (Teece, 1987).

Adding to an already large literature on the impact of firm size on organizational dynamics, our study offers two additional aspects. First, we found that size matters with respect to the types of relationships firms have with university research centers and the types of technology centrality strategic initiatives firms pursue, i.e. core versus non-core technologies. Second, our study reminds us that firm size is highly correlated with organizational structure (Burns and Stalker, 1961). However, our study goes beyond this notion to illuminate that an association appears to exist between firm size, firm structure, and a firm's competence building and problem solving initiatives. While we have clearly delineated competence building from problem solving these can in practice be closely related organizational activities that are not mutually exclusive (Ihde, 1993; Nonaka and Takeuchi, 1995). Thus, although we found certain sized organizations with certain structural characteristics more closely aligned with specific types of I/U relationships, we believe a firm's fluidness and flexibility is needed to foster the skillful blending of both competence building and problem solving. Some firms may be nimble and sophisticated enough to switch structures (Zmud, 1982). We think, however, it is more likely that firms pursuing both competence building and problem solving simultaneously (Itami and Numagami, 1992) seamlessly integrate characteristics of both mechanistic and organic structures by balancing order and disorder within their complex and dynamic organizational systems (Schoonhoven and Jelinek, 1997).

Despite a growing trend in I/U collaboration (Betz, 1996; Cohen et al., 1998; Okubo and Sjoberg, 2000) we found generally low levels of intensity across the four I/U relationship alternatives. While this was somewhat surprising, it suggests a tremendous opportunity exist for raising the level of industry's involvement in I/U alliances. Attractive policies tendered by university research centers, such as offering more flexible and creative reward policies for intellectual property rights and technology licensing agreements, are one way to further stimulate industry's involvement. While university research centers can be more successful in intensifying their relationships with industrial firms, a certain threshold does exist since industrial firms have only a limited amount of time and resources available for I/U activities. It may remain that different sized firms and those in different industrial sectors continue to use $\mathrm{I} / \mathrm{U}$ relationships in very narrow and targeted ways. The framework offered here could be beneficial to both industry and academe by providing new insights on ways these relationships can be established, employed, enhanced, and sustained.

A large literature stresses the importance of champions (e.g. Chakrabarti, 1974; Chakrabarti and Hauschildt, 1989; Howell and Higgins, 1990; Schon, 1963). Our results add to this literature by showing that not all champions are equal. We found that some champions may be more important than others. A champion usually plays an instrumental role in formulating and implementing an organization's strategies (van Dierdonck et al., 1990). Moreover, champions at the firm often influence the budgeting process ensuring that certain desired projects and activities get funded (Howell and Higgins, 1990; Pfeffer, 1981). Together, this may explain why we found champions at the firm more important to the intensity of I/U relationships than champions at the university research center. While this finding adds a new dimension to the current literature, much more must be learned. For example, the measure of champions in this study was rather general; it encompassed select activities related to the presence of an influential individual within the organization. Moreover, in developing our measure we followed the established notion that one individual in the organization performs all necessary functions related to successful boundary management. In contrast, Chakrabarti and Hauschildt (1989, 165 pp.) discussed "a division of labor in innovation management" where the champion often manifests as a multi-person constellation within the organization.

Chakrabarti and Hauschildt (1989) proposed that experts or fachpromotersare members of the 
organization who possess the technical knowledge and are most effective in idea generation and exploring internal technical mechanisms and limitations. Sponsors or machtpromoters are organizational members who control the organization's resources and are key decision-makers. Finally, the champion or process promoter has an overall knowledge of the organization, has diplomatic skills, and knows who should be and who should not be involved in various activities. Additionally, the champion or process promoter is the salesperson of new ideas and is the linkage between the expert or fachpromotor and the sponsor or the machtpromoter. Following Chakrabarti and Hauschildt's (1989) framework, our focus was centered on one person, the process promoter. Thus, while this study highlights the importance of a champion at the firm, additional insights are needed as to the possibility that more than one key individual at the firm may be affecting the dynamics in I/U relationships. The importance of a champion was noted in our interviews with several firms. When the budgets got leaner, the champions at higher levels in the corporate hierarchy were able to help sustain the support for the research centers.

In understanding the contribution of the university research centers, we speculate that much of the contributions can be explained in light of social capital theory (Coleman, 1988; Nahapiet and Ghoshal, 1998; Woolcock, 1998). Large companies are interested in associating with top tier or more prestigious universities for network effect (Santoro and Chakrabarti, 2001). Although top-tier universities do not usually work on problems that are of immediate significance to the firms, the firms benefit from interactions with not only the members of the faculty, but also other industrial participants. In their forthcoming book, Richard Lester and Michael Piore ${ }^{1}$ at Massachusetts Institute of Technology consider the university as a public space for knowledge exchange. University centers provide a forum for discussion and an "interpretive" process for the development of technology. They have concluded that "the most important contribution the research university can make to industry, above and beyond the quantity and quality of its graduates, is to help expose private companies to a broad range of new ideas. A company that demands an exclusive, proprietary research relationship may

\footnotetext{
${ }^{1}$ Private communication from Richard Lester to Chakrabarti.
}

not only be damaging the university, it may also be reducing the value that it will ultimately derive from that relationship" (Lester et al., 1998).

\subsection{Additional limitations and directions for future research}

We offer several new thoughts related to the dynamics of I/U alliances. However, as in most research, limitations do exist. First, our primary focus was on the industrial firm within the context of its relationships with university research centers. A potentially rich area of investigation in the future could concentrate on the complex integration of both industrial firm and university research center factors. Unexplored factors from this point of view might include such things as the compatibility of university center and industrial firm cultures, the lack of effective leadership at the firm and/or at the university research center, and conflicts between industrial firm and university center personnel. While we believe this line of investigation could provide additional insights, it requires a different focus and research design than was employed here.

Second, since the data used for hypotheses testing was both perceptual and largely retrospective, the interpretation of these results must be done carefully despite safeguards taken to limit various sources of bias. Moreover, since this study only provides a description of a complex phenomenon, a longitudinal design is needed to advance a causal model (Rosenthal and Rosnow, 1991).

Finally, our intent here was to examine I/U relationships within the parsimonious context of research centers affiliated with universities in the US. Although this allowed us to study a complex phenomenon within the rubric of a relatively broad and diverse sample of firms and university research centers, this study is confined to a particular model within US borders. A broader investigation examining $\mathrm{I} / \mathrm{U}$ collaborative ventures in a wider variety of university-based organizations in different countries could further extend and enhance these findings.

\section{Acknowledgements}

The authors would like to thank the Center for Innovation Management Studies and their corporate 
sponsors for providing financial support for this research. Thanks also to George Farris at Rutgers University, Saul Fenster at NJIT, and David Hawk at NJIT for their assistance in this research.

\section{References}

Acs, Z.J., Audretsch, D., 1990. Innovation and Small Firms. MIT Press, Boston.

Ali, A., 1994. Pioneering versus incremental innovation: review and research propositions. Journal of Product Innovation Management 11, 46-61.

Ancona, D., Caldwell, D., 1990. Improving the performance of new product teams. Research Technology Management 33 (2), 25-29.

Barney, J.B., 1991. Firm resources and sustained competitive advantage. Journal of Management 17, 99-120.

Bettis, R., Hitt, M., 1995. The new competitive landscape. Strategic Management Journal 16, 7-19.

Betz, F., 1996. Industry-university partnerships. In: Gaynor, G. (Ed.), Handbook of Technology Management. McGraw-Hill, New York (Chapter 8).

Bierly, P.E.III, Chakrabarti, A.K., 1996. Technological learning, strategic flexibility, and new product development in the pharmaceutical industry. IEEE Transactions on Engineering Management 43, 368-380.

Bower, D.J., 1992. Company and Campus Partnership. Routledge, London.

Bower, D.J., 1993. Successful joint ventures in science parks. Long Range Planning 26 (6), 114-120.

Browning, L., Beyer, J., Shetler, J., 1995. Building cooperation in a competitive industry: SEMATECH and the semiconductor industry. Academy of Management Journal 38 (1), 113-151.

Burns, T., Stalker, G.M., 1961. The Management of Innovation. Tavistock, London.

Chakrabarti, A., 1974. The role of champion in product innovation. California Management Review 17, 58-62.

Chakrabarti, A., Hauschildt, J., 1989. The division of labour in innovation management. R and D Management 19 (2), 161171.

Coleman, J.S., 1988. Social capital in the creation of human capital. American Journal of Sociology 94, S95-S120.

Corsten, H., 1987. Technology transfer from universities to small and medium-sized enterprises-an empirical survey from the standpoint of such enterprises. Technovation 6, 57-68.

Cohen, W., Levinthal, D., 1990. Absorptive capacity: a new perspective on learning and innovation. Administrative Science Quarterly 35, 128-152.

Cohen, W., Florida, R., Randazzese, L., Walsh, J., 1998. Industry and the academy: uneasy partners in the cause of technological advance. In: Noll, R. (Ed.), Challenges to Research Universities. The Brookings Institute Washington, DC, pp. 171-200.

Conner, K., Prahalad, C.K., 1996. A resource-based theory of the firm: knowledge versus opportunism. Organization Science 7, 477-501.
Cook, T., Campbell, D., 1976. The design and conduct of quasi-experiments and true experiments in field settings. In: Dunnette, M. (Ed.), Handbook of Industrial and Organizational Psychology. Rand McNally, Chicago, Ill., pp. 223-326.

Daft, R.L., 1978. A dual-core model o f organizational innovation. Academy of Management Journal 21, 193-210.

D'Aveni, R.A., 1994. Hypercompetition. Free Press, New York.

Deutch, J., 1991. Getting University-Industry Relations Right, Technology Review, May-June, 65 pp.

Deeds, D.L., DeCarolis, D., Coombs, J.E., 1998. Firm-specific resources. Firm-specific resources and wealth creation in high-technology ventures: evidence from newly public biotechnology firms. Entrepreneurship Theory and Practice 22, 55-73.

Evans, D., Starbuck, E., Kiresuk, T., Gee, R., 1993. Center for interfacial engineering: an experiment in building industry-university partnerships. International Journal of Technology Management 8, 622-651.

Fombrun, C., 1996. Reputation: Realizing Value From The Corporate Image. Harvard Business School Press, Boston.

Fortune, 1996. Will Outsourcing Save Corporate R\&D? 15 Jan, pp. $80 \mathrm{f}-80 \mathrm{j}$.

Foster, R., 1986. Innovation: The Attacker's Advantage. Summit Books, New York.

Frye, J., 1993. University-industry cooperative research yields dividends. International Journal of Technology Management 8, 577-586.

Geisler, E., 1995. Industry-university technology cooperation: a theory of inter-organizational relationships, technology analysis . Technology Analysis and Strategic Management 7, 217-229.

Gerwin, D., Kumar, V., Pal, S., 1992. Transfer of advanced manufacturing technology from canadian universities to industry. Technology Transfer 12, 57-67.

Gittelman, M., 2000. From Technology Transfer to Knowledge Acquisition: Effective Strategies for University-Firm Linkage. Academy of Management Meeting, August, Toronto.

Grant, R.B., Baden-Fuller, C., 1995. A knowledge-based theory of inter-firm collaboration. Academy of Management Best Paper Proceedings, 17-21.

Hair, J., Anderson, R., Tatham, R., Black, W., 1995. Multivariate Data Analysis. Upper Saddle River, Prentice-Hall, Englewood Cliffs, NJ.

Hamel, G., 1991. Competition for competence and inter-partner learning within international strategic alliances. Strategic Management Journal 12 (Summer Special Issue), 83-103.

Hamel, G., Prahalad, C.K., 1994. Competing For The Future, Harvard Business School Press, Boston.

Hauschildt, J., 1999. Promotors and champions in innovationsdevelopment of a research paradigm. In: Brockhoff, K., Chakrabarti, A., Hauschildt, J. (Eds.), The Dynamics of Innovation. Springer, New York, pp. 167-185.

Henderson, R.M., Cockburn, I., 1994. Measuring competence? Exploring firm effects in pharmaceutical research. Strategic Management Journal 15, 63-84.

Howell, J., Higgins, C., 1990. Champions of technological innovation. Administrative Science Quarterly 35, 317-341.

Ihde, D., 1993. Philosophy of Technology. Paragon Books, New York. 
Industrial Research Institute, 1995. Industry-University Research Collaborations: Report of a Workshop. National Academy of Sciences, Washington, DC.

Itami, H., Numagami, T., 1992. Dynamic interaction between strategy and technology. Strategic Management Journal 13, $119-135$.

Jarillo, J., 1988. On strategic networks. Strategic Management Journal 9, 31-41.

Kogut, B., 1988. Joint ventures: theoretical and empirical perspectives. Strategic Management Journal 9, 319-332.

Lado, A., Wilson, M., 1994. Human resource systems and sustained competitive advantage: a competency-based perspective. Academy of Management Review 19, 699-727.

Lawrence, R., 1984. Can America Compete? The Brookings Institute, Washington, DC.

Lawrence, P.L., Lorsch, J.W., 1967. Organization and Environment: Managing Differentiation and Integration. Harvard University Press, Boston.

Leonard-Barton, D., 1995. Wellsprings of Knowledge. Harvard Business School Press, Boston, MA.

Lester, R.K., Piore, M. J., Malek, K.M., 1998. Interpretive Management: What General Managers Can Learn from Design. Harvard Business Review, March-April, pp. 86-96.

Mansfield, E., 1991. Academic research and industrial innovation. Research Policy 20, 1-12.

Mowery, D.C., Oxley, J.E., Silverman, B.S., 1996. Strategic alliances and interfirm knowledge transfer. Strategic Management Journal 17, 77-91.

Nahapiet, J., Ghoshal, S., 1998. Social capital, intellectual capital and the organizational advantage. Academy of Management Review 23 (2), 242-266.

National Science Board, 1993. Science and Engineering Indicators. National Science Foundation. US Government Printing Office, Washington, DC.

National Science Board, 1996. Science and Engineering Indicators. National Science Foundation. US Government Printing Office, Washington, DC.

National Science Board, 2000. Science and Engineering Indicators. National Science Foundation. US Government Printing Office, Washington, DC.

National Science Foundation, 1982a. University-Industry Research Relationships: Myths, Realities, and Potentials, Fourteenth Annual Report. US Government Printing Office, Washington, DC.

National Science Foundation, 1982b. University-Industry Research Relationships: Selected Studies. US Government Printing Office, Washington, DC.

Nonaka, I., Takeuchi, H., 1995. The Knowledge Creating Company. Oxford University Press, Oxford, UK.

Okubo, Y., Sjoberg, C., 2000. The changing pattern of industrial scientific research collaboration in Sweden. Research Policy 29 (1), 81-98.

Oliver, A.L., Liebeskind, J.P., 1998. Three levels of networking for sourcing intellectual capital in biotechnology: implication for studying interorganizational networks, international studies of management. International Studies of Management and Organization 27 (4), 76-103.
Osborn, R., Hagedoorn, J., 1997. The institutionalization and evolutionary dynamics of inter-organizational alliances and networks. Academy of Management Journal 40 (2), 261-278.

Parkhe, A., 1993. Strategic alliance structuring: a game theoretic and transaction cost examination of inter-firm cooperation. Academy of Management Journal 36 (4), 794-829.

Pfeffer, J., 1981. Power in Organizations. Pitman, New York.

Pfeffer, J., Salancik, G., 1978. The External Control of Organizations: A Resource Dependence Perspective. Harper and Row, New York.

Phillips, D., 1991. New alliances for policy and the conduct of research and education. International Journal of Technology Management 6, 478-487.

Pisano, G., 1990. The R\&D boundaries of the firm: an empirical analysis. Administrative Science Quarterly 35, 153-176.

Prahalad, C.K., 1998. Managing discontinuities: the emerging challenges, Research Technology Management, 14-22.

Prahalad, C.K., Hamel, G., 1990. The core competence of the corporation, Harvard Business Review, 79-91.

Rea, D., Brooks, H., Burger, R., LaScala, R., 1997. The semiconductor industry-Model for industry university government cooperation, Research Technology Management, 46-54.

Reams, R., 1986. University-Industry Research Partnerships. Quorum Books, Westport, Conn.

Rosenthal, R., Rosnow, R., 1991. Essentials of Behavioral Research. McGraw-Hill, New York.

Rosner, M., 1968. Economic determinants of organizational innovation. Administrative Science Quarterly 12, 614-625.

Santoro, M., Chakrabarti, A., 1999. Building industry-university research centers: some strategic considerations. International Journal of Management Reviews 1 (3), 225-244.

Santoro, M., Chakrabarti, A., 2001. Corporate strategic objectives for establishing relationships with university research centers. IEEE Transactions on Engineering Management 48 (2), 157163.

Schon, D., 1963. Champions for radical new innovations. Harvard Business Review 41, 77-86.

Shan, W., Walker, G., Kogut, B., 1994. Inter-firm cooperation and start-up innovation in the biotechnology industry. Strategic Management Journal 15, 387-394.

Schoonhoven, C., Jelinek, M., 1997. Dynamic tension in innovative high technology firms: managing rapid technological change through organizational structure. In: Tushman, M., Anderson, P. (Eds.), Managing Strategic Innovation and Change. Oxford Press, New York.

Smith, J., McKeon, J., Hoy, K., Broyson, R., Shecter, L., Roberts, E., 1984. Lessons from 10 case studies in innovation. International Research Management, 23-27.

Smith, K., Carroll, S., Ashford, S., 1995. Intra- and interorganizational cooperation: toward a research agenda. Academy of Management Journal 38 (1), 7-23.

SRI International, 1997. The Impact on Industry of Interaction with Engineering Research Centers. Science and Technology Program, Washington, DC.

Steele, L., 1989. Managing Technology. McGraw-Hill, New York. Stone, E.F., Hollenbeck, J.R., 1988. Clarifying some controversial issues surrounding statistical procedures for detecting moderator variables: empirical evidence and related matters. Journal of Applied Psychology 74, 3-10. 
Teece, D., 1987. Profiting from technological innovation: implications for integration, collaboration, licensing and public policy. In: Teece, D. (Ed.), The Competitive Challenge. Ballinger, Cambridge, MA.

Teece, D.J., Pisano, G., Shuen, A., 1997. Dynamic capabilities and strategic management. Strategic Management Journal 18, 509-533.

van Dierdonck, K., Debackere, K., Engelen, B., 1990. Universityindustry relationships: how does the Belgian academic community feel about it? Research Policy 19, 551-566.

van Rossum, W., Cabo, P., 1995. The contribution of research institutes in EUREKA projects. International Journal of Technology Management 10, 853-866.

Wernerfelt, B., 1984. A resource-based view of the firm. Strategic Management Journal 5, 171-180.

Woolcock, M., 1998. Social capital and economic development: toward a theoretical synthesis and policy framework. Theory and Practice 27, 151-208.

Zmud, R.W., 1982. Diffusion of modern software practices: influence of centralization and formalization. Management Science 28, 1421-1431. 